\title{
Thinking Creativity as an Indicator of Student's Academic Achievement
}

\author{
*Agung Slamet Kusmanto, Universitas Negeri Malang, Malang, Indonesia, \\ agung.slamet.1601119@students.um.ac.id \\ Punaji Setyosari, Faculty of Education, Department of Guidance and Counselling, Universitas Negeri Malang, \\ Malang, Indonesia Indonesia, punaji.setyosari.fip@um.ac.id \\ Adi Atmoko, Faculty of Education, Department of Guidance and Counselling, Universitas Negeri Malang, \\ Malang, Indonesia Indonesia, adi.atmoko.fip@um.ac.id \\ IM. Hambali, Faculty of Education, Department of Guidance and Counselling, Universitas Negeri Malang, \\ Malang, Indonesia Indonesia, im.hambali.fip@um.ac.id
}

\begin{abstract}
Individuals have their own uniqueness. From such uniqueness it can produce something different through the way of thinking. Divergent thinking encourages students to have alternative answers to varying possibilities, but convergent ways of thinking can provide the correct answer of the possible alternative answers. This way of thinking can encourage student creativity. Students can see the possibilities of creative thinking and creative behavior to create something either in the form of thinking, problem solving, or a new product. Creativity supports academic achievement. Creative attitude can be developed through the process of education in which students are trained to be able to think creatively through problems that require divergent and convergent thinking continuously, so that in the future it can also support the career development of students to achieve their success.
\end{abstract}

Keywords: divergent, convergent, creative thinking, academic achievement Received: 22.11.2020 $\quad$ Accepted: 10.12.2020 $\quad$ Published: 16.01 .2021

\section{INTRODUCTION}

The National Education System Act of 2003 states that education is a conscious and planned effort to create an atmosphere of learning and learning processes so that learners actively develop their own potential to have religious spirituality, personal controlling, personality, intelligence, noble character and skills needed by self, society, nation and state. From the above passage then each individual is required to develop himself. Individuals certainly have their own uniqueness, without exception in their development. Self-development is a tool in developing talent, potential and creativity. Maybe, some of us think that creative thinking is a very special thing. Many people are able to think creatively compared to others. Creative thinking is one of the best ways to survive in life. By thinking creatively, then we will be more respected and not considered as ordinary human in general. Creative thinking can be said to be the strangest activity of the human brain, and has therefore become an eternal source of attraction in the history of human progress. But over the centuries, this ability to produce new things has been interpreted as a mysterious gift, rejecting a rational explanation as possible. Indeed, an act is just to explain creativity which is seen as endangering inspiration and strangling the possibility for a flow toward the far away land of fantasy (Corazza \& Agnoli, 2016).

To be called as a creative person, one must have some characteristics which are not the same as people in general. Wagner (2015) reveals that creative people have 2 supporting elements namely the aspect of cognition and affection aspects. Cognition aspect relates to creative thinking, while the affection (non-aptitude) aspect relates to attitudes, feelings and emotions. Creative people are not genius ones, otherwise creative people are flexible and seek solutions in an unexplored field (Dale, 2002). The followings are the nature of the so-called creative personality:

1. Sensitivity to the environment.

2. Flexible, open, inquisitive, and selective

3. Free Assessment 


\section{Tolerance to disguise}

5. Mental flexibility.

So to be creative requires ideas and courage and belongs to minorities. Creative thinking is a very complex mental process involving many skills and traits, as well as a number of cognitive, social, and motivational abilities (Corazza \& Agnoli, 2016). We can conclude that, in terms of cognitive aspect, creativity can be seen through originality, flexibility, fluency, and elaboration. While, from non-cognitive perspective it can be seen from the motivation of attitude and creative personality. These two traits are both important; the intelligence that is not supported by the creative personality will not produce anything. Creativity can only be born from intelligent people who have a healthy psychological condition. Creativity is not only the actions of the brain but emotional and mental health variables are also very influential on the birth of a creative work. Extraordinary intelligence will still not produce creative work if not supported by a healthy mental.

The success of individuals in getting through the level of education and career is always expected by all individuals. As we have seen around us that the benchmark of success in the perspective of our society is that individuals are considered successful if in education somebody achieves the highest education and can reach the top position in career. In this case creative thinking can be a way to achieve success in terms of education and career. At the level of thinking we recognize two thinking styles, i.e. divergent and convergent thinking, although in the most famous model versions according to Stanberg (2003), there are five operations, six products, and four content. The five operations are cognition, memory, divergent production, convergent production, and evaluation.

In problem solving divergent thinking gives a tremendous influence in performing various possible answers. And this way allows students to have creative thinking without having to determine the correctness and mistakes of the answer. This tendency, if getting a good response from teachers, will very possibly enable students to learn to analyze in correct ways and can be a field of work so that the number of choices in creative thinking is much better. When we look at the students at this point, nowadays not a few students have divergent thinking, for example many students do action in various ways without thinking whether what is done is appropriate or not or not referring to norms of truth, but just a matter of "likes or dislikes". This is in accordance with the research of Kilgour \& Koslow (2009) which shows higher convergence-oriented skill level in strategic thinking $(.176$ versus $-.155, \mathrm{p}=.01)$. From the research, in addition to having many alternative answers, to think convergently is highly needed because it is concerned with the results that will be gained in the future.

On the thinking side this is one of the characteristics of people who have a creative tendency are those who have the ability of divergent thinking. This is in line with Guilford's opinion (in Munandar, 1992) which states that divergent thinking or the pattern of thought that produces ideas, is the most obvious indicator of creative person. A creative person will provide creative behavior. Munandar (1992) states that creative behavior can be realized from the cognitive (ability to think creative) and affective aspect (attitude and value). The more creative a person is the more possible for him to have characteristics of creative student. Further Utami Munandar (1992) describes the cognitive (creative thinking) features that include fluent thinking skills, broad thinking skills, original skills, detailed skills and judgment skills. So if a student is focusing his/her mind to be able to find a particular problem solving then the student is considered thinking convergently, and if the student is looking for some possible settlement (solutions) this means that the student is thinking divergently. This gives the sense that divergent thinking skills open up students' opportunities for creative thinking.

Divergent and convergent thinking can be seen through the test, this is in accordance with a research conducted by Shiu (2011):

"creative and divergent thinking is different based on the possibility of having many answers, so as not to cause limitations of respondents' thinking. Although different thinking questions do not show specific answers, there is clear initial information. The scale of cognitive evaluation for different thinking tests (such as the newly designed creativity test, test of the Torrance verbal thought creation, and figural test used in this study) was adopted to evaluate fluency, flexibility, originality, and elaboration. The situation for creative problem solving does not involve a specific beginning or purpose. Truth answers are not evaluated by a certain standard. However, by using creative problem-solving training, we can identify whether learners have the cognitive ability to effectively improve different thinking and to improve problem-solving behavior (belief in problem solving, emotional control or self-action, and courage to overcome problems) ."

The above findings are supported by one of the most striking findings of a study (KiSoon Han \& Christine Marvin.2002) that different measures of thought do not have great power in predicting creative performance at least in two of three, if not all, domains assessed in this research. None of the divergent thinking 
tests provided in this study, separately or in battery, predicted the real creative behavior of 109 children. The number of variance described by two divergent thinking tests in collage and mathematical tasks is relatively small. The findings of both studies complement and evolve with prior research. This result is in line with previous studies that different sizes of thought are often weak but significantly related to creative activity in the language domain (e.g, storytelling, writing), but not to creative behavior in other realms (Baer, 1991; Runco, 1986 ). Current results show the possibility of verbal bias in different thinking tests; however, the use of only one nonverbal subtest (from the Wallach-Kogan Creativity Test) in this study may have contributed to this outcome.

Christine A. Toh \& Scarlett R. Miller (2015) conducted a study of the impact of personality and risk of creative attitudes, which results from empirical studies on engineering students revealing that, teams that have higher levels of awareness, friendliness, and tolerance for more ambiguity which is vvulnerable to choosing new concepts. In addition, the results reveal that teams that produce creative ideas do not always choose creative ideas during conceptual selection. These results add to our understanding of team-based decisionmaking during conceptual election and allow providing guidance for improving the flow of creative ideas. So the study provides an overview of the selection of concepts in producing creative ideas that can make decisions in team work. So this team can work and can be done in the student's education. With group assignments given by teachers students have opportunity to exchange ideas with group members so as to generate some alternative answers that shape student's critical thinking.

Creative ideas can also be generated through habituation and a growing culture where the student lives more specifically the school as a place that is used everyday to learn. Socioeconomic circumstances usually bring ideas that can support success in the field of education and career. This is in line with the findings of Amber yaying wan (2011) who see that creativity can be formed from several factors one of which is very strongly formed from the social and cultural students where they live. The role of families, schools and communities also indirectly gives a tremendous impact on creativity, so that it supports the advancement of education and careers.

\section{DISCUSSION}

Guilford (1967) considers creativity as an intellectual ability and thought process that requires different thinking. Guilford suggests that sensitivity to problems, fluency, originality, elaboration and redefinition as a component of creativity. According to Stanberg (2008) creativity is a potential thing to create and implement the idea of something new and has a high quality. This creativity involves attitude, motivation, personality, and environmental components as one of creative intelligence.

In line with the above understanding, Chen, F. (2010) puts forward "creativity is a mental process that produces unique solutions, ideas, concepts, artistic, theory, or product". Meanwhile according to Stenberg (2003) creativity is "the process of producing something original and valuable". "Creative thinkers, however, confronted with the same open ended question, are careful not to rush to judgment. They recognize that there are many possible solutions and are willing to "go wide" first, identifying a number of possible approaches before converging on the ideas most worth implementing" (Tom \& David Kelly, 2015). This means that creative thinkers somehow refer to the possibilities that may be solved and identify possible approaches to be implemented. Similarly, according to De bono (2015), "creative different ways of thinking will be especially useful for generating new ideas and solving problem". So creative thinking has ideas that refer to new ideas and problem solving.

Creative techniques vary depending on the extent to which they encourage a divergent or convergent process, although they most focus on divergent thinking. Different thinking techniques facilitate connections from previously unrelated memory nodes. In other words they encourage distant domain associations. Convergent techniques focus on the problem domain and encourage new relationships between ideas within the domain.

Munandar (2002) explains that thinking diverges as a mental operation that demands the use of creative thinking skills, including fluency, flexibility, originality, elaboration and collaboration. This means that someone is said to think divergently in solving problems if he/she meets the following four criteria: fluency of thinking, flexibility, originality, and elaboration. The four criteria are summarized as follows: (a) the smoothness of a person to produce many ideas; (b) the flexibility of thinking is the ability of a person to produce ideas composed of different categories or the ability to perceive objects, situations or problems from different points of view; (c) originality or often called unconventional thinking is a form of thinking authenticity about 
something that has not been thought of by others or is not the same as people's thoughts in general; (d) elaboration is the ability to detail a central idea into smaller ideas.

Practitioners have seen an increase in the process of creative thinking using different techniques so that the main unusual concepts were used in the idea generation process (de Bono 1968). The earliest example, called Synetics (Gordon 1961), encouraged the combination of related ideas over the distance by forcing respondents to combine ideas from different domains. This is the idealization skill that is the focus of measurement in creativity tests (Clapham 1997). This technique encourages an associative process in order that the primary non-domain information is used in a creative combination process. Interviews with personal creative advertising show that they use a variety of internal self-taught associative techniques to aid their ideamaking process (Kilgour 2008). Creativity techniques, such as word associations or metaphorical usage, distinguish major concepts and force respondents to think across domains to produce more original solutions (Baughman and Mumford 1995; McFadzean 2000).

Lew, Kyoung-Hoon (2015) suggests that the social and cultural environment in which creativity can be expressed is vital for producing creative output. Therefore, creativity can be defined as a student's ability, integrated with his character, to create new, unique products and in accordance with contemporary situations. Amber yaying wan (2011) sees creativity can be formed from several factors one of which is very strongly formed from social and culture of the student where they live. In addition to the research that some researchers have pointed out, there are significant differences in the culture of each student, so the culture affects the students' creativity. (Niu \& Sternberg, 2003; Ogawa et al., 1991; Rudowicz, Lok \& Kitto, 1995; Saeki, Fan, \& Van Dusen, 2001). Although some refer to the results of the study but do not explain the difference, only (Niu \& Sternberg, 2003; Saeki, Fan, \& Van Dusen, 2001) provide reasons for the difference in collectivism and individualism as a possible factor.

Culture is an influence of the development of student creativity, therfore Indonesia, as a country formed from various tribes and cultures, also has students of different degrees. As a plural country, the development of creativity becomes one of the indicators. Because it is a country consisting of various cultures, it is increasingly influencing the attitude of creativity of its citizens, but there is research from Valentin Lupu (2013), entitled Effect of Academically Giftedness on Creativity whose results show that giftedness really has no effect on 15 creative attitudes being measured: energy, concentrations, orientation, have no creative relationship with creative attitude (novelty, idea reasoning, independence, noncom formality, self confidence, moral value, far future orientation, finality, risk, attraction for difficult problem, , Spiritual values, practical values.). Hence, we can see that academic giftedness does not correlate with students' creative attitudes. In this case the creative attitude can be grown through the field of education in accordance with the points of view argued by Runco (2004) asserting that creative behavior can be developed through education. He emphasized that there is a difference of creativity between children and adulthood, but creativity education is very important and must be done in different ways.

Through education students can be nurtured and trained to become students who have creative behavior, so that on the development of creativity it can also produce a person who has creative thoughts and behaviors. This affects the progress in teamwork in their future career, whether as an employee or an employer, individual can take advantage of all the circumstances without any obstacles in progress. Through teamwork, creative attitudes and behaviors can strengthen the group, both in education and in relationships with colleagues. Lew, Kyoung-Hoon (2015) conducted a study on comparative individual and group creativity, First, individual creativity was significantly correlated with group creativity. Secondly, the total score, as well as the specific fluency and conformity scores are significantly higher for individual creativity than group creativity.

Recent research supports this position by confirming that specific interventions focused on a particular domain are far more effective than the general "preferential treatment", which usually offer "all-purpose" enrichment programs for all types of gifted children (Bloom, 1985; Csikszentmihalyi, Rathunde, Sc Whalen , 1993: Treffinger Sc Feldhusen, 1996). Great evidence suggests that our gifted children are poorly served by standard enrichment programs that do not take seriously their individuality into account (U.S. Education Office, 1993). However, this does not mean that we should ignore the general teaching program of general thinking skills or problem-solving skills in schools today. Even with all the negative things mentioned above, there is no doubt that improving children's thinking and problem-solving skills in different areas is an important educational goal (Treffinger, 1986; Treffinger Sc Feldhusen, 1996). In fact, the ability to think creatively in general can and should continue to be encouraged in every domain and area of talent. Individual and domainbased approaches, which are coordinated with current programs to teach thinking skills or problem-solving skills, however, may be the best way to address the diversity of our school systems. 
Today, a broad paradigm shift in the field of gifted education occurs: the movement of "talent development" (Csikszentmihalyi, Rathunde, Sc Whalen, 1993; Gagne, 1985; Renzulli, 1994; Treffinger, 1995; Treffinger Sc Feldhusen, 1996; VanTassel-Baska, 1997). Educators of gifted children are challenged to consider the proposition that the recognition and development of talents among children is the most important contribution to education (Feldman, 1980, Treffinger, 1995). Clearly, the notion of specificity of creativity specifications seems to reflect current trends, and the talent development approach strongly supports identification.

In general education is the learning of knowledge, skills, and habits of a group of people descended from one generation to the next through teaching, training, or research. Education often takes place under the guidance of others, but also allows self-taught. Any experience that has a formative effect on the way people think, feel, or act can be considered educational. Education is generally divided into stages such as preschool, primary school, high school and then college, university or apprenticeship (Wikipedia) in Indonesia currently using Curriculum 2013 which aims to prepare Indonesian people to have the ability to live as individuals and citizens who are believing and productive, creative, innovative, and affective and able to contribute to the life of society, nation, state, and world civilization. The 2013 curriculum is developed with a philosophical foundation that provides the foundation for the development of all potential learners into qualified Indonesian human beings listed in national education objectives. The cornerstone of this philosophy is used in developing the individual lives of learners in the religious, art, creativity, communicating, values and various dimensions of intelligence that fit a learner and the needs of society, nation and humanity.

So the way of studying in school provides many opportunities to create student creativity. One of the learning strategies undertaken in shaping the creative process of students is experiential learning strategy. Shiu et.al (2011) suggests that problem-solving skills through experiential learning strategies is by positioning learners as centers, for their experience with themselves, so that learning can be effective. Therefore, in addition to building an open atmosphere, learning activities team work, with Group competition and rewards are used in the classroom to encourage learning motivation. The students who take innovative creation and management courses in the human resource development department are selected for experimental samples. In seven weeks (three hours during a week) of teaching, the context includes 1 . creative ideas for problem solving and knowledge 2. creative tactics divergence 3. creative tactics of convergence solving task work problems 4. team practice 5. daily life and selfexperiment like case for troubleshooting practice. This study uses three types of meters to evaluate the effectiveness of learning, which is a newly designed creativity test (including verbal and figural forms), Torrance thinking creativity tests (including verbal and figural forms), creativity scale problem solving. Compare with the score in the results, the post test is higher than the pretest significantly, and solve the problem test is higher than the normative data significantly as well.

Chen (2008) uses three objectives of course design, namely cognition, compassion, and skills to develop nine goals for creativity training and seven instructional strategies. The results showed that cognition and affection of students in the experimental group increased significantly; However, the effect of training on creative life experiences is insignificant. Under the advancement of computer technology, there are electronic brainstorming technologies that use decision support systems to enhance traditional brainstorming, and such technology is applied to creative problem solving. Tools similar to e-conference systems have better suited for virtual or remote group interaction (Wang and Chen, 2006).

We need to consider the actual educational functions as follows: 1). Preparing community members to earn a living, which means that education will ultimately support in his career and work so that it can be used as a support for the welfare of his life. 2). Developing individual talents for personal satisfaction and for the benefit of society, education is a tool in developing talent, so as to develop creativity so as to provide usefulness for the community. 3). preserving culture, and 4). instilling the necessary skills for participation in democracy.

Although the literature suggests that divergent thinking techniques have a positive effect on originality, the problem persists regarding this technique (Mark Kilgour \& Scott Koslow, 2009). Although the meta-analysis of Scott et al (2004) shows that creativity training improves the performance of respondents, only three of 70 studies have examined the effectiveness of creativity training in non-student samples. Another concern is that the actions used to assess creative thinking techniques emphasize originality or novelty, often ignoring problem solving and performance criteria related to the aspects of creativity fit (Scott et al., 2004b). Taking into account the limitations of the process, it is hoped that this technique will improve originality. Petrowski, Mary Jane (2017) "Life creates more possibilities by engaging with opportunities." Get involved in everything with the opportunity to learn. Just as creativity requires isolation and privacy, stimulation, novelty, and new experiences 
as well as fuel. So learning is a means to cultivate the creativity of students, so that ultimately the success of students in the field of education and career can be achieved through creative thinking and behavior.

\section{CONCLUSION}

Each student has the ability to succeed, both in the field of education and in the career. Through education students can cultivate divergent and convergent ways of thinking. Divergent thinking gives various alternatives for solutions while convergent thinking encourages students to be able to choose alternative answers so as to provide a correct assessment in their completion. Students can develop their creativity through such education, because education it facilitates students in developing creative ways of thinking. Through education students can be creative and have a variety of ways in solving the problem, so that students are expected to achieve success both in the field of academics and career in the future. Success in education and careers is a pride that all individuals want to achieve.

\section{REFERENCES}

A Dale Timpe. 2002. Seri Manajeman Sumber Daya Manusia Kreativitas. Elek media komputindo. Jakarta.

Baer, J. 1991. Generality of creativity across performance domains. Creativity Research Journal, $4,23-39$.

Baughman, W. A., \& Mumford, M. D. 1995. Process analytic models of creative capacities: Operations influencing the combination-and- reorganization process. Creativity Research Journal, 8, 37-62. doi: 10.1207/s15326934crj0801_4.

Bloom, B. S. (Ed.). 1985. Developing talent in young people. New York: Ballantine.

Chen, Febe. 2010. Be Creative : Menjadi Pribadi Kreatif. Jakarta: Gramedia Pustaka Utama

Chen,Yu-Shu .2008. The effect of the Creativity Training program: Quasi Soloman Four-Group Design. Curriculum \& Instruction Quarterly. vol.11, No.4, 187-211.

Christine A. Toh $\bullet$ Scarlett R. Miller. 2015. Creativity in design teams: the influence of personality traits and risk attitudes on creative concept selection. /Published online: 21

November 2015 (C) Springer-Verlag London 2015. Res Eng Design (2016) 27:73-89 DOI 10.1007/s00163-015-0207-y

Clapham, M. M. 1997. Ideation skills training: a key element in creativity training programs. Creativity Research Journal, 10(1), 33-44. doi:10.1207/s15326934crj1001_4.

Corazza, Giovanni Emanuele and Agnoli., Sergio 2016. On the Path Towards the Science of Creative Thinking. (C) Springer Science+Business Media Singapore 2016 G.E. Corazza and S. Agnoli (eds.), Multidisciplinary Contributions to the Science of Creative Thinking, Creativity in the Twenty First Century, DOI 10.1007/978-981-287-618-8_1

Csikszentmihalyi, M. 1988. Society, culture, and person: A system view of creativity. In R.J. Sternberg (Ed.), The nature of creativity (pp. 325-339). New York: Cambridge University Press.

Csikszentmihalyi, M., Rathunde, K., \& Whalen, S. (1993). Talented teenagers: The roots of success and failure. New York: Cambridge University Press.

De bono Edwards. 2015. The master of creative thinking. Vermilion, an imprint of ebury publishing. London

de Bono, E. 1968. New think: the use of lateral thinking in the generation of new ideas. New York: Basic.

Gordon, W. J. J. 1961. Synetics: the development of creative capacity. New York/Evanston/London: Harper \& Row.

Guilford, J.P. 1967. The nature of human inntelegece, new York. McGrow-Hill

Han, Ki-Soon \& Marvin, Christine.2002. Multiple Creativities? Investigating DomainSpecificity of Creativity in Young Children. MULTIPLE CREATIVITIES 98 GIFTED CHILD QUARTERLY • SPRING 2002・VOL 46 NO 2

Kemdikbud, 2013, Rencana Strategis (Renstra) Kementerian Pendidikan dan Kebudayaan Tahun 2010-2014

Kilgour, A. M. 2008. Understanding creativity: the creative thinking process and how to improve it. Staarbrucken Germany VDM Verlag.

Kilgour, Mark \& Koslow, Scott. 2009. Why and how do creative thinking techniques work?: Trading off originality and appropriateness to make more creative advertising. J. of the

Acad. Mark. Sci. 37:298-309 DOI 10.1007/s11747-009-0133-5 
Lew, Kyoung-Hoon. 2015. A Comparison of Group and Individual Creativity. International Information Institute (Tokyo). Information; Jun 2015; 18, 6(B); Technology Collection pp.2707-2711

Lupu, Valentin, 2013. Effect Of Academically Giftedness On Creativity. Social-Behavioural Sciences revista academiei fortelor terestre $\mathrm{nr} .2$ (70)/2013

Munandar, SC Utami. 1992. Mengembangkan Bakat dan Kreativitas Anak Sekolah. Jakarta: Gramedia.

Munandar, U. 2002. Kreativitas \& Berbakat : Strategi Mewujudkan Potensi Kreatif \& Bakat. Jakarta: PT Gramedia Pustaka Utama

Niu w \& Stanberg, RJ. 2003. Societal and School Influences On Student Creativity: The Case of China. Psychology in the schoo, 40 (1). 103-114

Ogawa, M., Kuen-Ebert, C.,\& Devito A. 1991. Differences In Creative Thinking Between Japanese and America Fifth Grade Children. Ibraki University Faculty Of Education Buleetin. 40. 53-59

Petrowski, Mary Jane. 2017. Creativity research: implications for teaching, learning and thinking. Emerald Group Publishing Limited Reference Services Review; Bradford Volume: 28, Issue: 4 Pages: 304-312

Rudowics, E., Lok, D., \& Kitto, J. 1995. Use of the torrence test of creative thinking in an exploratory study of creativity in hongkong primary school children: cross-cultural comparison. International journal of psychology. 30(4), 417-430

Runco, . Mark A. 2007. Creativity "Theories and Themes: Research, Development, and Practic". Elsevier Academic Press

Runco, M. A. 1986. Divergent thinking and creative performance in gifted and nongifted children. Educational and Psychological Measurement, 46, 375-384.

Runco, M.A. 2004. Creativity, Annual Review of psychology, 55

Saeki, N, Fan,X \& Van dusen, L. 2001. A comparative study of creative thinking of American and Japanese college student. Journal of creative behavior, 35(1), 24-36.

Scott, G. M., Leritz, L. E., \& Mumford, M. D. 2004. The effectiveness of creativity training: a quantitative review. Creativity Research Journal, 16(4), 361-388. doi:10.1207/s15326934crj1604_1.

Shiu, Shih-Ching and Ruey-Gwo Chung \& Hsiu-O Chien. 2011. A Study Of Learning Process To Promote The Ability Of Creativity And Creative Problem Solving In The Technological University Student. International Journal of Arts \& Sciences, CD-ROM. ISSN: 1944-6934 :: 4(8):31-36 (2011) Copyright (C) 2011 by InternationalJournal.org

Stanberg, J Robert. 2003. Wisdom, Intellegence, and Creativity Synthesized. Cambridge University Press.

Stanberg, J Robert. 2009. Academic intelegence is not Enough!: WISC; An expanded Model for

Effective Practice in School and in Later Life. Mosakowski Institute for Public Enterprise

Treffinger, D. J., Sc Feldhusen, J. F. (1996). Talent recognition and development: Successor to gifted education. Journal for the Education of the Gifted, 19, 181-193 Wagner, tony. 2015. Creating innovators. The gale group. America

wang , Amber yaying. 2011. Context of creative thinking: a comparison on creative performance of student teachers in Taiwan and US. Journal of international and cross cultural studies, vol 2 issues 1

Wang, J.W. and Chen, M.D. 2006. Creativity-the method and tool of Creative Problem sovling. Tingmao Publish Company, Taipei. 